\title{
Inter-African Labour Conference
}

THE fourth session of the Inter-African Labour Conference organized by the Commission for Technical Co-operation in Africa South of the Sahara (CCTA) was held in Beira (Mozambique) from I2 to 22 August 1955. It was attended by delegates from most of the African territories as well as from Belgium, France, Portugal, and the United Kingdom. Progress made in connexion with the recommendations of previous conferences (held in Jos, Northern Nigeria; Bamako, French Sudan; and Élisabethville, Belgian Congo) were studied and the difficulties they encountered were examined. The housing of workers was seen to be a major problem in all territories. Several recommendations were made in connexion with productivity of labour; human relations were considered to be one of the most important factors, and the establishment of consultative machinery on which management and workers were represented was strongly urged. The need for a common language to facilitate communication between workers and between workers and supervisors was also emphasized.

\section{Les Facteurs humains de la Productivité en Afrique Équatoriale Frangaise}

THE human factor in industrial productivity in Africa, which was one of the topics discussed at the Inter-African Labour Conference, was the subject of a survey made in French Equatorial Africa, under the direction of the Inspecteur Général du Travail et des Lois Sociales (M. Pelisson) and the Centre d'Étude des Problèmes du Travail. The survey was carried out by the Director of the Centre (Dr. Latouche) and a psychologist attached to the centre (Madame Dormeau). Their report was published at Brazzaville in April x955. The authors of the Report in their introduction describe the purpose of the survey as being to observe 'le comportement, dans son milieu physique at humain, du travailleur africain d'A.E.F. devant les problèmes posés par la productivité dans le cadre d'une économie moderne'. They point out that the economic development of the country is of very recent date, and also has been extremely rapid, so that reliable and adequate statistics are not available and would, moreover, quickly become out of date. They have, therefore, concentrated upon an accurate description of the facts observed. The Report gives a brief account of climatic and hygienic conditions, and then proceeds to discuss the attitude of the worker to his work; the traditional background; motives for seeking salaried employment; the effects on productivity of various stimuli-social, economic, professional; relations with other workers-Africans of different tribal groups or Europeans. One section is devoted to a consideration of methods for improving the stability of the labour force and increasing productivity; the last section describes in detail the systematic ' rationalisation ' carried out by one fairly long-established enterprise, under the direction of a specialist in industrial organization.

In conclusion the authors of the Report note that, although the various factors have been analysed separately, they are in practice inseparable, and they attempt to indicate certain 'vues de synthèse'. They point out that 'le fait colonial ' necessarily has an impact on all aspects of productivity-human, technical, and economic. Initially there is a divergence of interests between employers and African workers, but this is temporary, and it becomes increasingly necessary, if industry is to flourish, that the interests of all those associated in it should coincide. To arrive at this result, African workers must be offered incentives of various kinds. These will include increased financial gains resulting in a higher standard of living, increased social and professional status, and the possibility of attaching significance to the work itself. The professional training of Africans should be developed as rapidly as possible so that they may progressively replace Europeans in industry. 